\title{
Hypo-versus Hyper-thyroidism in 2 Cats: The Culprit for Miliary Dermatitis/Hypersensitivity Versus Growth Retardation
}

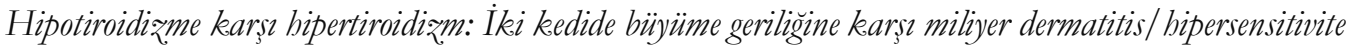

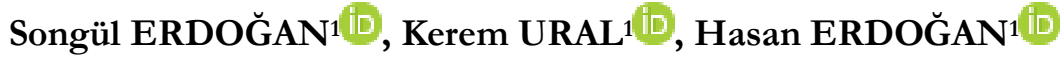

${ }^{1}$ Aydın Adnan Meneres University, Faculty of Veterinary, Departmant of Internal Medicine, Aydın, Turkey

\begin{abstract}
In the present case series 2 different cats with diagnosis of hypo- versus hyper-thyroidism with distinct clinical signs were reported. The first case was a 3-month-old male domestic short-hair kitten was presented with a disproportionate dwarfism. Radiographic examination of the long bones revealed epiphyseal dysgenesis and delayed epiphyseal ossification. Congenital primary hypothyroidism was established by low serum total thyroxine and initial treatment composed of levothyroxine. The second case was referred to the clinic with unresolved dermatological problems. On referral alopecia, extensive crusting and matting of the haircoat were evident. Hyperthyroidism and related military dermatitis was detected based on elevated serum total thyroxine and free T4 levels along with skin punch biopsy results. Therapeutical armamentarium composed of methimazole and hyperimmune milk factor. In conclusion, early recognition, diagnosis and treatment caused to intervention all resulted in clinical remission and relief of clinical signs accompanied by normal thyroidal function and laboratory results in both cats.
\end{abstract}

Keywords: Cat, Dermatitis, Dwarfism, Hypothyroidism, Hyperthyroidism.

Öz: Bu olgu sunumunda iki farklı kedide karşılaşılan hipotiroidizme karşı hipertiroidizm ilişkili farklı klinik bulgular sunuldu. İlk olgumuz 3 aylık yaşta, erkek, short-hair 1rk1 yavru kedi olup cücelik şikayeti ile kliniğimize getirilmiştir. Radyografik bulgularında uzun kemiklerde epifiziyal disgenezis ve epifiziyal kemikleşmede geçikme tespit edildi. Kongenital hipotiroidzm tanısı düşük total tiroksin seviyesiyle desteklendi ve levotiroksin ile sağaltıma başlanıldı. İkinci olgumuz ise sağaltıma rağmen düzelmeyen dermatolojik bulgular ile kliniğimize başvurdu. Klinik muayenede alopesi, yaygın kabuklanma ve k1l örtüsünde matlaşma görüldü. Deriden alınan punç biyopsi sonuçları, artan serum total tiroksin ve serbest T4 ve ilişkili miliyer dermatitis ile hipertiroidizm tanısı konuldu. Bu olgumuzda metimazol ve hiperimmun süt faktörü başlanıldı. Sonuç olarak her iki olgumuzda da erken tanı ve sağaltım ilişkili klinik bulguların giderilmesine, laboratuvar sonuçlanna göre normal tiroid fonksiyonlanna kavuşmalanna yol açtı.

\begin{tabular}{ll}
\hline \multicolumn{2}{l}{ Anahtar Kelimeler: Cücelik, Dermatitis, Hipotiroidzm, Hipertiroidzm, Kedi. } \\
\hline${ }^{*}$ Corresponding author : Songül ERDOĞAN & e-mail : songultp.09@gmail.com \\
Geliş tarihi / Received : 04.12.2019 & Kabul tarihi / Accepted: 16.12.2019 \\
\hline
\end{tabular}

\section{Introduction}

Hyperthyroidism, one of the most frequent endocrine disorder in middle to older aged cats (Peterson, 1986; Feldman and Nelson, 1996; Hibbert, 2018), denote excessive production of thyroid hormones due to abnormally functioning thyroidal tissue (Volckaert et al., 2016a). The incidence of hyperthyroidism in cats has been elevated since it was recognized. Regarding hyperthyroid cats, solely $5 \%$ of are younger than 10 years of age during initial diagnosis (Mooney, 2010; McLean et al., 2014; Stephens et al., 2014; Scott-Moncrieff, 2015).

Congenital hypothyroidism in cats is a rare disorder resulting with disproportionate dwarfism (Scott-Moncrieff, 2007; Johnson and Watson, 
2010). Diseased kittens characteristically present short skull and limbs, spine, block-like trunks (Arnold et al., 1984; Crowe, 2004; ScottMoncrieff, 2007; Szabo and Wells, 2007; Lim et al., 2014). Growth retardation, altered mental status, neuromuscular deficits, retention of hair coat, and other relevant signs might be detected in hypothyroid kittens (Feldman and Nelson, 2004; Scott-Moncrieff 2007; Szabo and Wells, 2007; Pettigrew et al., 2007; Johnson and Watson, 2010; Quante et al., 2010; Bojanic et al., 2011).

Two articles indicated the importance of hyperthyroidism among cats i.e. part I (anatomy, physiology, diagnosis and imagining) (Volckaert et al., 2016a) and part II (scintigraphic diagnosis and relevant treatment (Volckaert et al., 2016b), which prompted the present authors to publish the case series herein. Furthermore the present author's interest was also aroused following receipt of two different cats, 1 with hypo- and the other with hyper-thyroidism with specifical clinical findings and treatment.

\section{Case Report}

\section{Case I: hypothyroiditic cat}

Initial examination revealed disproportional short legs and abducted elbows. As being informed by the owner the cat was obstipated and anorectic. Facial structure of the cat resembled that of a very small aged kitten, although at time of referral it was 3 months of age (Figure 1). It was also interesting that the cat was mentally dull, with very slow respond to stimuli. The owner also informed that the cat was not playing with toys or its brother belonging to the same litter. The cat was $0.78 \mathrm{~kg}$, even if a normal weight for a domestic shorthair kitten of that age must be around or above $2 \mathrm{~kg}$.

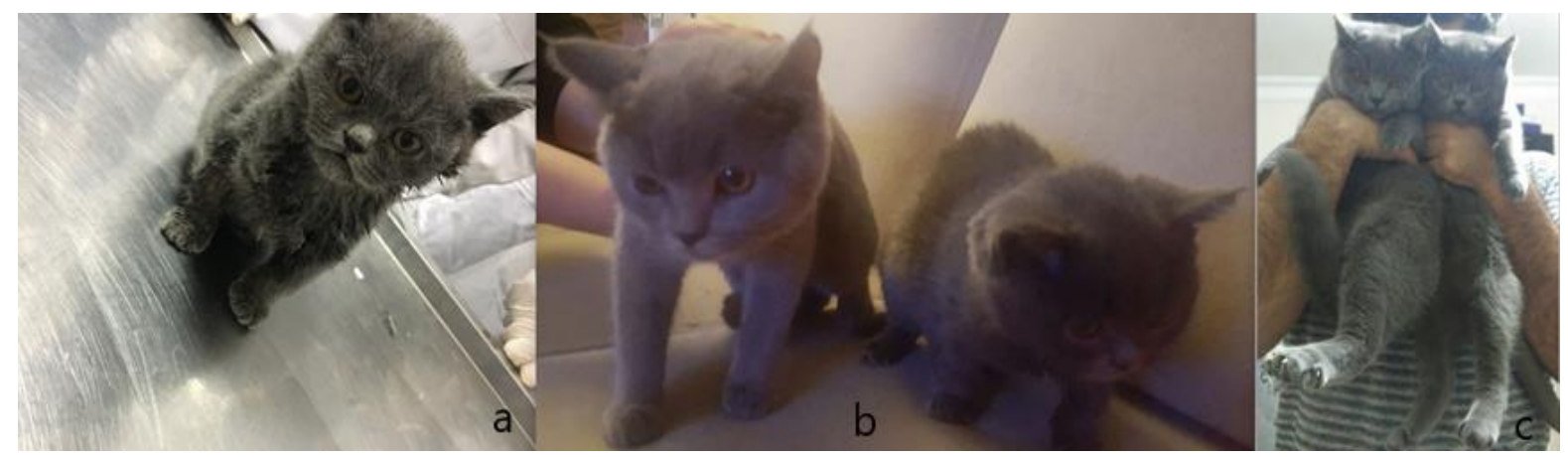

Figure 1. a) Hypothyrodic cat b) Hypothyroditic cat shown on the right along with her brother which was born on the same litter. Both cats were 3 months of age, whereas the present case was lethargic, showed failure to growth. c) both normal and hypothyroidic cats shown at 7 months of age (2 months of methimazole treatment).

Serum total T4 levels were lower than the reference ranges $(0.5 \mu \mathrm{g} / \mathrm{dL}$; reference range 0.8 $4.7 \mu \mathrm{g} / \mathrm{dL})$. Fecal examination was negative and not deemed any parasite. Beside antiparasitic medication was available previously. The cat was prescribed for levothyroxine $(0.05 \mathrm{mg} \mathrm{q} 12 \mathrm{~h}$ orally), lactulose (1.5 mL q 8 h orally) along with warm water enema, as was also described previously (Traas et al., 2008).

\section{Case II: cat with hyperthyroidism}

The first case was referred to the clinic with unresolved dermatological lesions [(miliary dermatitis, erythema, erosion and crusting) (Figure 2)]. As being informed by the owner the cat was hypersensitive and referred to several Veterinary Clinics with varying duration of diarrhea, unresponsive to traditional treatment. Up to date there was no precise diagnosis nor thyroidal profile was analyzed. On initial referral the cat was overactive, aggressive, with evidence of 
tachyarrhythmia (210 bpm). Miliary dermatitis, erythema and crusting were detected on rear legs, profile, anti-nuclear antibody test were all performed (Table 1).

lumbal area. Serum biochemistry, endocrine

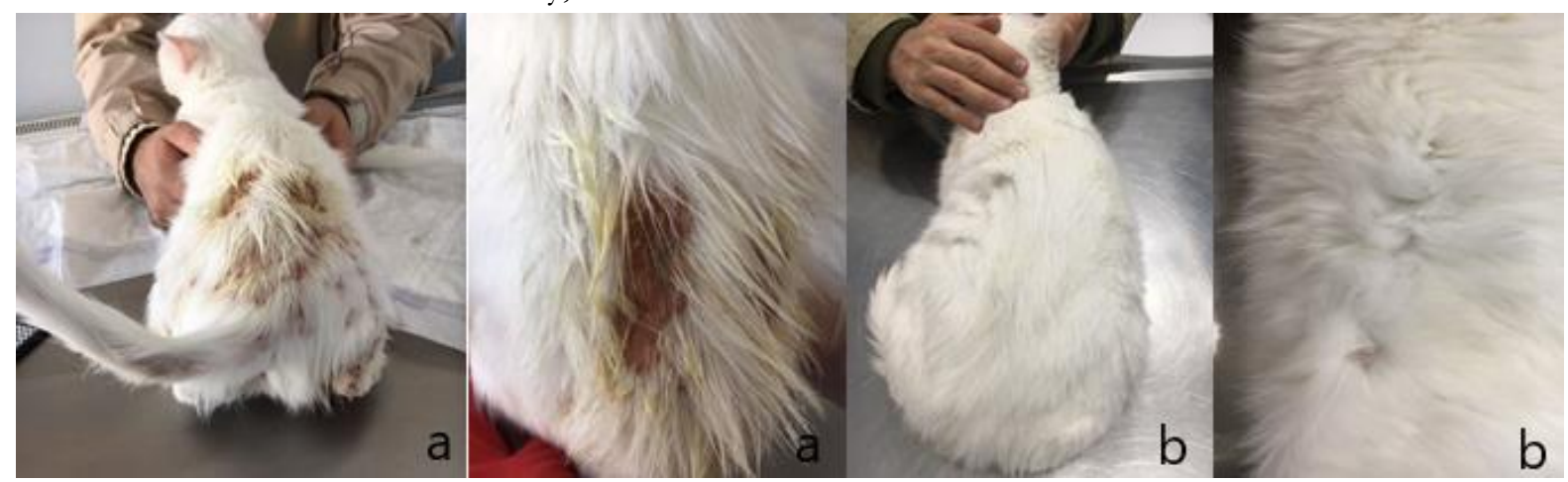

Figure 2. Miliary dermatitis along with severe crusting and erythema. Photographic record was taken on at a) initial examination and b) 2 months of therapy including methimazole and hyperimmune milk factor.

Table 1. Thyroidal panel in two different cats; Case I: Cat with hypothyroidism and case II: Cat with hyperthyroidism.

\begin{tabular}{lllll}
\hline Parameters & \multicolumn{3}{l}{ Case I } & \multicolumn{2}{l}{ Case II } \\
\hline \multirow{2}{*}{ Total T4 (ug/dL) } & day 0 & day 70 & day 0 & day 70 \\
\cline { 2 - 5 } Free T4 (pmol/L) & 0.5 & 2.8 & 11.9 & 2.6 \\
Total T3 (ng/mL) & 0.77 & 2.1 & 21.4 & 39.5 \\
Plasma cortisole (ug/dL) & 0.5 & & 0.92 & - \\
Growth hormone & 5.2 & & - & 256 \\
SomatomedinC(IGF-1) & 0.8 & 2.5 & - & - \\
Clinical findings & 80.2 & 467 & - & - \\
Available data & F.g., H.in & Di, Tachy., Wl \\
\hline
\end{tabular}

Di: diarrhea, Tachy: tachycardia, Wl: weight loss, F.g.: failure of growth, H.in: heat intolerance, T.p.: thyroid panel, S.b.: serum biochemistry, P.biop.: punch biopsy, E.p.: endocrin panel (plasma cortisole)

For treatment, methimazole $(2,5 \mathrm{mg} / \mathrm{cat})$ and hyperimmune milk factor were applied during two months. Before treatment regime skin punch biopsy $(6 \mathrm{~mm})$ was performed. For this, local anesthesia with $0,3 \mathrm{ml}$ lidocaine $2 \%$ was injected by subcutaneously surrounding the selected lesion. After anesthesia, biopsy punch was placed on selected area and observed biopsy samples was transferred to $\% 10$ formalin.

\section{Discussion}

In the vast majority of cats with hyperthyroidism weight loss, hyperactivity, increased body temperature, diarrhea, cardiovascular problems (tachycardia or other relevant arrhythmias, systolic murmurs, hypertrophic cardiomyopathy, tachypnea, dyspnea), altered behavior, stress intolerance, muscle weakness/ atrophy, hair coat changes, polyuria/polydipsia, systemic hypertension, polyphagia, vomiting, increased frequency of defecation (Bucknell, 2000; Mooney, 2010; Klein, 2012; Peterson, 2014; ScottMoncrieff, 2015). The atypical form of hyperthyroidism, also known as apathetic or masked hyperthyroidism, is associated with signs of depression and anorexia, often still accompanied by weight loss. It is important to keep in mind that not all hyperthyroid patients demonstrate the typical clinical presentation and 
signs may be subtle, especially in early stages (Bucknell, 2000). Some of hyperthyroid cats present excessive grooming behavior causing alopecia or crusty rash, accompanied with intense itching resembling miliary dermatitis (Peterson, 2012). The latter condition might be in relation with with an underlying allergy, whereas dermatological alterations could reflect cat's obsessive and compulsive behavior (i.e. elevated licking and grooming) (Peterson, 2011). In one of the present cases herein reported clinical signs mimicking hyperthyroidism were diarrhea, tachycardia and weight loss. Besides striking and interesting clinical feature was miliary dermatitis in which should be on the list of differential diagnosis for hyperthyroidism (Peterson, 2011).

Hyperimmune milk factor (microlactin) was the drug of choice for relieving hypersensitivity and miliary dermatitis in case I of this article. Regarding the efficacy of microlactin; it inhibits and reverses neutrophil attachment to the blood vessel wall-stabilizing inactivated neutrophils unable to participate in inflammation (Beck and Fuhrer, 1993; Okubo et al., 2016). Furthermore it is able to maintain proper actioning of another inflammatory cell, macrophages with proven invitro and invivo effects (Gingerich and Strobel, 2003; Bello and Allen, 2005). Taking into account crusting dermatosis in cats, small circumscribed crusts of feline dermatitis might be found, in which the most commonly observed allergic dermatitis is flea allergy (Carlotti, 2004). There might be also crusts related to excoriations located on to the dorsolumbar area (Carlotti, 2004), which was similar to the case $\mathrm{I}$ in this article. Feline eosinophilic plaque (Gross et al., 1986) and miliary dermatitis (Carlotti, 2004) both mimic clinical findings of allergic skin disease, in which dermal inflammation composed of eosinophils, mast cells, lymphocytes and neutrophils (Gross et al., 2005). In the present case with hyperthyroidism, $6 \mathrm{~mm}$ skin punch biopsy was performed prior to treatment application, in which histopathology revealed mixed inflammatory infiltrate reach in mast cells along with erosion and ulceration.
Therefore, it may be safely suggested that microlactin may have helped clinical recovery and relieving inflammation.

Taking into account growth failure in cats and dogs, related endocrine causes are GH/IGF-1 deficiency, excessive glucocorticoids, hypothyroidism, hypoadrenocorticism, diabetes mellitus and vitamin D disorders (Scott-Moncrieff, 2015). In the present case with hypothyroidism diagnosis was based on low levels of total T4 and fT4, along with normal blood glucose, cortisol and vitamin D levels. Besides early recognition of the disease and effective levothyroxine treatment all resulted in growth of the kitten, which supported precise/tentative diagnosis.

In conclusion the good (well prognosis and respond to treatment), the bad (the clinical signs) and the ugly (serum biomarkers i.e. endocrine profile) parts of two distinct thyroidal disorders; hypo- vs. hyper- thyroidism have been documented herein at the same time. Early recognition, real time diagnosis within the necessary biomarkers and prompt treatment might overcome thyroidal diseases among cats.

\section{References}

Arnold, U., Opizt, M., Grosser, I., Bader, R., Eigenmann, J.E., 1984. Goitrous hypothyroidism and dwarfism in a kitten. Journal of the American Animal Hospital Association 20, 753-758.

Beck, L.R., Fuhrer, J.P., 1993. Milk lymphocyte antiadhesion factor, and its role as an anti-microbial. In: International Dairy Federation, Uppsala, Sweden, 6272.

Bello, T.R., Allen, T., 2005. The Use of MicroLactin ${ }^{\circledR}$ for Inflammatory Conditions in Equine Veterinary. Journal of Equine Veterinary Science 25(9), 380-382.

Bojanic, K., Acke, E., Jones, B.R., 2011. Congenital hypothyroidism of dogs and cats: A review. New Zealand Veterinary Journal 59, 115-122.

Bucknell, D.G., 2000. Feline hyperthyroidism: spectrum of clinical presentations and response to carbimazole therapy. Australian Veterinary Journal 78, 
$462-465$.

Carlotti, D.N., 2004. Crusting Dermatoses in Cats. In: World Small Animal Veterinary Association World Congress Proceedings, Cabinet de Dermatologie Vétérinaire, Heliopolis B 3 Bordeaux-Mérignac, France.

Crowe, A., 2004. Congenital hypothyroidism in a cat. Canadian Veterinary Journal 45, 168-170.

Feldman, E.C., Nelson, R.W., 1996. Canine and Feline Endocrinology and Reproduction. WB Saunders, Philadelphia.

Feldman, E.C., Nelson, R.W., 2004. Feline hypothyroidism. In: Feldman, E.C., Nelson, R.W., (Eds.), Canine and Feline Endocrinology and Reproduction, Saunders Elsevier, Philadelphia, pp. 143-151.

Gingerich, D.A., Strobel, J.D., 2003. Use of clientspecific outcome measures to assess treatment effects in geriatric, arthritic dogs: controlled clinical evaluation of a nutraceutical. Veterinary Therapeutics 4(1), 56-66.

Gross, T.L., Ihrke, P.J., Walder, E.J., Affolter, V.K., 2005. Spongiotic and vesicular diseases of the epidermis. Feline eosinophilic plaque. In: Gross, T.L., Ihrke, P.J., Walder, E.J., Affolter, V.K., (Eds.), Skin Diseases of the $\operatorname{dog}$ and cat. Clinical and histopathological diagnosis. Blackwell Science, USA, pp. 105-115.

Gross, T.L., Kwochka, K.W., Kunkle, G.A., 1986. Correlation of histologic and immunologic findings in cats with miliary dermatitis. Journal of the American Veterinary Medical Association 189, 1322-1325.

Hibbert, A., 2018. Common feline enteropathies: a cas based approach. In: BSAVA Congress Proceedings, BSAVA Library, pp. 71-72.

Johnson, K.A., Watson, A.D.J., 2010. Skeletal diseases. In: Ettinger, S.J., Feldman, E.C., (Eds.), Textbook of Veterinary Internal Medicine. Saunders Elsevier, Philadelphia, pp. 819-845.

Klein, B.G., 2012. Endocrine glands and their function. In: Klein, B.G., (Eds.), Cunningham's Textbook of Veterinary Physiology. Saunders Elsevier, St. Louis, Missouri, USA, pp. 428 - 464.

Lim, C.K., Rosa, C.T., De Witt, Y., Schoeman, J.P., 2014. Congenital hypothyroidism and concurrent renal insufficiency in a kitten. Journal of the South African Veterinary Association 85(1), 6.
McLean, J.L., Lobetti, R.G., Schoeman, J.P., 2014. World- wide prevalence and risk factors for feline hyperthyroid- ism: a review. Journal of the South African Veterinary Association 85, 1097.

Mooney, C.T., 2010. Hyperthyroidism. In: Ettinger, S.J., Feldman, E.C., (Eds.), Textbook of Veterinary Internal Medicine. Saunders Elsevier, St. Louis, Missouri, USA, pp. 1761 - 1779.

Okubo, K., Kamiya, M., Urano, Y., Nishi, H., Herter, J. M., Mayadas, T., Kurosawa, M., 2016. Lactoferrin suppresses neutrophil extracellular traps release in inflammation. EBio Medicine, 10, 204-215.

Peterson, M.E., 1986. Hyperthyroidism in cats. In: Chastain, C.B., Ganjam, V.K., (Eds.), Clinical endocrinology of companion animals. Lea and Febiger, Philadelphia, pp. 110-175.

Peterson, M.E., 2011. Top 10 Signs of Hyperthyroidism Top 10 Signs of Hyperthyroidism in Cats.

http://www.animalendocrine.info/2011/05/top-10signs-of-hyperthyroidism-in-cats.html (Access Date: 24.11.2019).

Peterson, M.E., 2014. Feline hyperthyroidism: an animal model for toxic nodular goiter. Journal of Endocrinology 223, 97-114.

Pettigrew, R., Fyfe, J.C., Gregory, B.L., Lipsitz, D., Delahunta, A., Summers, B.A., Shelton, G.D., 2007. CNS hypomyelination in Rat Terrier dogs with congenital goiter and a mutation in the thyroid peroxidase gene. Veterinary Pathology 44, 50-6.

Quante, S., Fracassi, F., Gorgas, D., Kircher, P.R., Boretti, F.S., Ohlerth, S., 2010. Congenital hypothyroidism in a kitten resulting in decreased IGF1 concentration and abnormal liver function tests. Journal of Feline Medicine and Surgery 12, 487-490.

Scott-Moncrieff, J.C., 2007. Clinical signs and current diseases of hypothyroidism in dogs and cats. Veterinary Clinics of North America Small Animal Practice 37, 709-722.

Scott-Moncrieff, J.C., 2015. Feline hyperthyroidism. In: Feldman, E.C., Nelson, R.W., Reusch, C., ScottMoncrieff, J.C., Behrend, E., (Eds,), Canine and Feline Endocrinology. Saunders Elsevier, St. Louis, Missouri, USA, pp. $136-195$.

Stephens, M.J., O’Neill, D.G., Church, D.B., McGreevy, P.D., Thomson, P.C., Brodbelt, D.C., 2014. Feline hyper- thyroidism reported in primary-care 
veterinary practices in England: prevalence, associated factors and spatial distribution. Veterinary Record 175, 458.

Szabo, S.D., Wells, K.L., 2007. What is your diagnosis?. Journal of the American Veterinary Medical Association 230, 29-30.

Traas, A.M., Abbott, B.L., French, A., Giger. U., 2008. Congenital Thyroid Hypoplasia and Seizures in 2 Littermate Kittens. Journal of Veterinary Internal Medicine 22(6), 1427-1431.

Volckaert, V., Vandermeulen, E., Daminet, S., Saunders, J., Peremans, K., 2016a. Hyperthyroidism in cats, part I: anatomy, physiology, pathophysiology, diagnosis and imaging. Vlaams Diergeneeskundig Tijdschrift 85(5), 255-264.

Volckaert, V., Vandermeulen, E., Daminet, S., Saunders, J., Peremans, K., 2016b. Hyperthyroidism in cats, part II: scintigraphic diagnosis and radioiodine treatment. Vlaams Diergeneeskundig Tijdschrift 85(5), 265-273. 